\title{
Analisis Antropometri Petani Dan Aplikasinya Pada Desain Alat Pemanen Manggis
}

\author{
Sella Fiana ${ }^{1}$, Wahyu Kristian Sugandi ${ }^{2}$, Ahmad Thoriq $^{3}$, Asep Yusuf ${ }^{4}$ \\ ${ }^{1,2,3)}$ Departemen Teknik Pertanian dan Biosistem, Fakultas Teknologi Industri Pertanian Universitas \\ Padjadjaran \\ sellafiana@gmail.com \\ doi: https://doi.org/10.24843/JEI.2019.v05.i01.p04
}

Article Received: 14 Juni 2019; Accepted: 28 Juni 2019; Published: 30 Juni 2019

\begin{abstract}
Abstrak
Pemanenan manggis saat ini dilakukan secara manual dengan cara memanjat pohon atau menggunakan alat panen sederhana yang terbuat dari bambu. Guna meningkatkan produktivitas, perlu didesain alat panen manggis dengan mengacu pada antropometri pemanen. Data antropometri dikumpulkan dari 30 (tiga puluh) pemanen manggis yang meliputi tinggi badan, tinggi bahu, tinggi lutut, panjang lengan, jangkauan tangan keatas menggenggam, jangkauan tangan kedepan menggenggam, panjang telapak tangan, diameter ibu jari ke jari telunjuk, dan diameter ibu jari ke jari tengah. Pembuatan alat mengacu pada data persentil ke-5 untuk mendapatkan dimensi alat yang maksimal untuk petani yang memiliki tubuh pendek dan nyaman untuk yang memiliki tubuh tinggi. Hasil penelitian menunjukkan rata-rata tinggi badan pemanen adalah $150 \mathrm{~cm}$, tinggi bahu $125 \mathrm{~cm}$, tinggi lutut 37,92 cm, panjang lengan 47,62 cm, jangkauan tangan keatas menggenggam 177,54 cm, jangkauan tangan kedepan terbuka 65,67 cm, jangkauan tangan kedepan menggenggam $59,45 \mathrm{~cm}$, diameter genggaman ibu jari ke jari telunjuk $37,70 \mathrm{~mm}$, dan diameter genggaman ibu jari ke jari tengah adalah 44,17 mm. Berdasarkan data antropometri tersebut didapatkan desain alat panen menggunakan sistem teleskopik dengan panjang $3 \mathrm{~m}$ yang dapat dipendekkan menjadi $1,5 \mathrm{~m}$, diameter galah $3,2 \mathrm{~cm}$, dan bentuk penampung buah manggis menyerupai huruf " $\mathrm{V}$ " dengan konstruksi terbuat dari plat aluminium.
\end{abstract}

Kata kunci: Antropometri, alat panen, manggis

\section{Anthropometric Analysist And It's Application Of Mangosteen Harvesting Tool Design}

\begin{abstract}
Harvesting of mangosteen is manually by climbing trees or using simple harvesting tools that made from bamboo. In order to increase productivity, it is necessary to design mangosteen harvesting equipment by referring to harvesting anthropometry. Anthropometric data were collected from 30 (thirty) mangosteen harvesters which included height, shoulder height, knee height, arm length, hand reach up to grip, front hand reach, palm length, index finger and thumb diameter to the middle finger. The making of the tool refers to the 5th percentile data to get the maximum dimension of the tool for farmers who have SMAll and comfortable bodies for those who have large bodies. The results showed that the average harvesting height was $150 \mathrm{~cm}$, shoulder height $125 \mathrm{~cm}$, knee height $37.92 \mathrm{~cm}$, arm length $47.62 \mathrm{~cm}$, hand reach above grip $177.54 \mathrm{~cm}$, forward hand reach $65.67 \mathrm{~cm}$, the front hand reaches $59.45 \mathrm{~cm}$, the thumb grip diameter to the index finger $37.70 \mathrm{~mm}$, and the thumb grip diameter to the middle finger is $44.17 \mathrm{~mm}$. Based on the anthropometric data, the design of the harvesting equipment was obtained using a telescopic system with a length of $3 \mathrm{~m}$ which can be shortened to 1.5
\end{abstract}


$m$, the diameter of the handle $3.2 \mathrm{~cm}$, and the shape of the mangosteen fruit resembling the letter " $V$ " with an aluminium plate construction.

Key words: Anthropometric, harvesting tool, mangosteen.

\section{PENDAHULUAN}

Manggis merupakan salah satu komoditas buah tropika yang memiliki nilai ekonomis yang tinggi dan merupakan komoditas unggulan ekspor, namun produksi dan volume ekspor buah manggis pada tahun 2012 hingga tahun 2017 mengalami fluktuasi, padahal permintaan ekspor terus mengalami peningkatan (BPS, 2017; Muslim dan Nurasa, 2009; Kustiari, dkk, 2012). Salah satu faktor yang menyebabkan menurunnya produksi dan volume ekspor buah manggis adalah belum diterapkannya budidaya manggis yang sesuai dengan anjuran pemerintah, diantaranya tidak menggunakan bibit unggul, kurangnya pemeliharaan tanaman, dan penggunaan pupuk di bawah dosis yang dianjurkan, kurangnya perhatian pemerintah, terhadap pengembangan komoditas manggis, penanganan panen dan pascapanen manggis yang masih tradisional (Muslim dan Nurasa, 2009; Nuraniputri, dkk., 2016).

Kegiatan panen dan pascapanen merupakan salah kegiatan yang berpengaruh langsung terhadap mutu buah manggis yang dihasilkan. Pemanenan manggis dapat dilakukan dengan cara memanjat pohon dan memetik buah manggis satu persatu dengan menggunakan tangan. Selain dengan memanjat, pemanenan manggis dapat dilakukan dengan menggunakan alat panen. Penggunaan alat panen yang belum memenuhi standar berpotensi menyebabkan buah manggis yang dipanen terjatuh dari pohon dan menyebabkan buah mengalami pengerasan kulit, warna permukaan kulit buah menjadi coklat, warna daging yang menjadi bening, serta timbulnya getah di sela-sela daging buah (Gunadnya, dkk., 2001).

Alat panen yang digunakan petani saat ini belum di desain sesuai dengan pendekatan antropometri, padahal alat yang di desain secara ergonomis dengan menggunakan data antropometri dapat meningkatkan produktivitas pemanenan (Vyavahare dan Kallurkar, 2012). Menurut Mugisa (2016) desain alat yang optimal membutuhkan penerapan yang komprehensif dan konteks dimensi tubuh yang spesifik dengan antropometri ataupun dengan dimensi tubuh. Menurut Sutalaksana dan Widyanti (2016) data antropometri yang valid dan jelas akan sangat penting dalam melakukan desain peralatan dalam lingkungan kerja. Data antropometri merupakan prasyarat untuk merancang alat dan peralatan pertanian yang memungkinkan pekerja mencapai kinerja dan produktivitas yang lebih baik sambil memberikan keamanan dan kenyamanan yang lebih baik (Syuaib, 2015).

Hal ini menunjukkan penting adanya pengukuran antropometri petani, sehingga penelitian ini dilakukan analisis data antropometri dan gerak kerja petani untuk mendesain alat pemanen manggis yang ergonomis. Tujuan dari penelitian ini adalah mendesain alat pemanen dengan menggunakan data antropometri dan mengetahui selang alami gerak kerja pada saat proses pemanenan manggis.

\section{METODE}

Penelitian dilakukan pada bulan Maret sampai dengan Mei 2019, bertempat di perkebunan manggis Kecamatan Puspahiang, Kabupaten Tasikmalaya, Provinsi Jawa Barat. Alat yang digunakan untuk pengukuran antropometri antara lain, meteran, jangka sorong, timbangan, silinder, mistar dan meteran pita, sedangkan alat yang digunakan untuk pembuatan alat panen adalah mesin bubut, obeng, dan penggores.

Bahan yang dipergunakan untuk subjek penelitian antara lain data antropometri, pohon manggis, vidio postur kerja, sedangkan alat yang digunakan untuk pembuatan alat panen 
manggis adalah dural aluminium dan batang aluminium dengan ketebalan $1 \mathrm{~mm}$ dan diameter 1 inchi dan 1,25 inchi. Responden pada penelitian ini berjumlah 30 orang yang seluruhnya adalah pemanen manggis yang telah berpengalaman lebih dari 5 tahun. Pengukuran tubuh petani manggis dilakukan secara bertahap menggunakan meteran, meteran pita, dan jangka sorong. Data hasil pengukuran dikelompokkan kedalam persentil 5, persentil 50, dan persentil 95.

Metode pengambilan data selang alami gerak saat petani melakukan proses pemanenan menggunakan alat panen dilakukan melalui pengambilan video pada 3 (tiga) pemanen. Data video yang telah diambil diolah menjadi gambar untuk bagian gerakan yaitu saat buah tepat masuk kedalam tangkai pengait, saat pemetikan buah, dan setelah pemetikan buah. Gambargambar tersebut dibuat sudut-sudut gerakan untuk setiap bagian menggunakan software AutoCad, sehingga dapat diketahui gerakan mana yang memiliki sudut yang tergolong masih dalam batas aman dan batas ekstrim pada zona selang alami gerak.

Penelitian ini diawali dengan pengumpulan data antropometri pemanen, pengumpulan data video pemanenan, pengukuran data alat pemanen. Data yang didapatkan selanjutnya dianalisis yang digunakan sebagai dasar dalam pembuatan alat panen manggis.

\section{HASIL DAN PEMBAHASAN}

Hasil pengukuran antropometri dari 30 petani manggis didapatkan beberapa parameter yang berpengaruh terhadap desain alat pemanen manggis yang disajikan pada Tabel 1 .

Tabel 1.

Parameter antropometri yang terkait dengan model alat panen

\begin{tabular}{|c|c|c|c|c|c|}
\hline No & Parameter Yang Diukur & Rerata & $\begin{array}{c}\text { Simpang } \\
\text { Baku }\end{array}$ & Persentil 5 & Persentil 95 \\
\hline & Berat badan $(\mathrm{kg})$ & 58,08 & 10,57 & 40,69 & 75,48 \\
\hline 2 & Tinggi badan $(\mathrm{cm})$ & 160,02 & 6,49 & 149,34 & 170,69 \\
\hline 3 & Tinggi mata $(\mathrm{cm})$ & 144,88 & 25,61 & 102,75 & 187,01 \\
\hline 4 & Jangkauan tangan kedepan terbuka $(\mathrm{cm})$ & 72,37 & 4,07 & 65,67 & 79,07 \\
\hline 5 & Jangkauan tangan kedepan menggenggam $(\mathrm{cm})$ & 65,43 & 3,64 & 59,45 & 71,41 \\
\hline 6 & Jangkauan tangan keatas terbuka $(\mathrm{cm})$ & 200,58 & 9,03 & 185,73 & 215,44 \\
\hline 7 & Jangkauan tangan keatas menggenggam $(\mathrm{cm})$ & 193,30 & 9,58 & 177,54 & 209,06 \\
\hline 8 & Panjang lengan $(\mathrm{cm})$ & 56,03 & 5,12 & 47,62 & 64,45 \\
\hline 9 & Keliling genggaman tangan $(\mathrm{cm})$ & 26,84 & 1,40 & 24,53 & 29,15 \\
\hline & Diameter ibu jari ke telunjuk (mm) & 44,81 & 4,32 & 37,70 & 51,92 \\
\hline & Diameter ibu jari ke jari tengan (mm) & 51,45 & 4,42 & 44,17 & 58,72 \\
\hline 12 & Tinggi bahu $(\mathrm{cm})$ & 133,72 & 5,70 & 124,35 & 143,09 \\
\hline & Tinggi lutut $(\mathrm{cm})$ & 43,32 & 3,28 & 37,92 & 48,71 \\
\hline
\end{tabular}

Berdasarkan parameter pada Tabel 1, nilai persentil yang diperhitungkan dalam analisis antropometri adalah persentil 5 yang mewakili dimensi petani bertubuh kecil dan persentil 95 yang mewakili dimensi petani manggis bertubuh besar (Arisandy, 2013). Rerata digunakan untuk mengetahui nilai rerata dari petani manggis yang menggunakan alat panen dengan tidak memperhatikan kecil atau besarnya tubuh petani manggis.

Persentil yang digunakan dalam pembuatan alat adalah persentil 5, hal tersebut menunjukkan bahwa 5\% populasi petani memiliki ukuran tubuh kecil sehingga jika menggunakan persentil 5 alat yang dibuat memungkinkan mendapatkan panjang batang alat 
yang sesuai dan petani yang memiliki ukuran tubuh besar akan merasa nyaman menggunakan alat panen. Tinggi badan petani digunakan perhitungan rerata yaitu $160 \pm 6,49 \mathrm{~cm}$. Untuk persentil 5, tinggi mata yaitu $102,75 \pm 25,61 \mathrm{~cm}$, jangkauan tangan ke depan terbuka $65,67 \pm 4,07 \mathrm{~cm}$, jangkauan tangan ke depan menggenggam 59,45 $\pm 3,64 \mathrm{~cm}$, jangkauan tangan ke atas terbuka $185,73 \pm 9,03 \mathrm{~cm}$, jangkauan tangan ke atas mengenggam $177,54 \pm 9,58 \mathrm{~cm}$, keliling genggaman tangan $24,53 \pm 1,40 \mathrm{~cm}$, diameter ibu jari ke telunjuk $37,70 \pm 4,32 \mathrm{~cm}$, diameter ibu jari ke jari tengah $44,17 \pm 4,42 \mathrm{~cm}$, tinggi bahu $124,35 \pm 5,70 \mathrm{~cm}$, dan tinggi lutut $37,92 \pm 3,28 \mathrm{~cm}$. Berdasarkan parameter yang terdapat pada Tabel 1, maka dilakukan penggambaran model manekin antropometri pemanen manggis yang disajikan pada Gambar 1 .

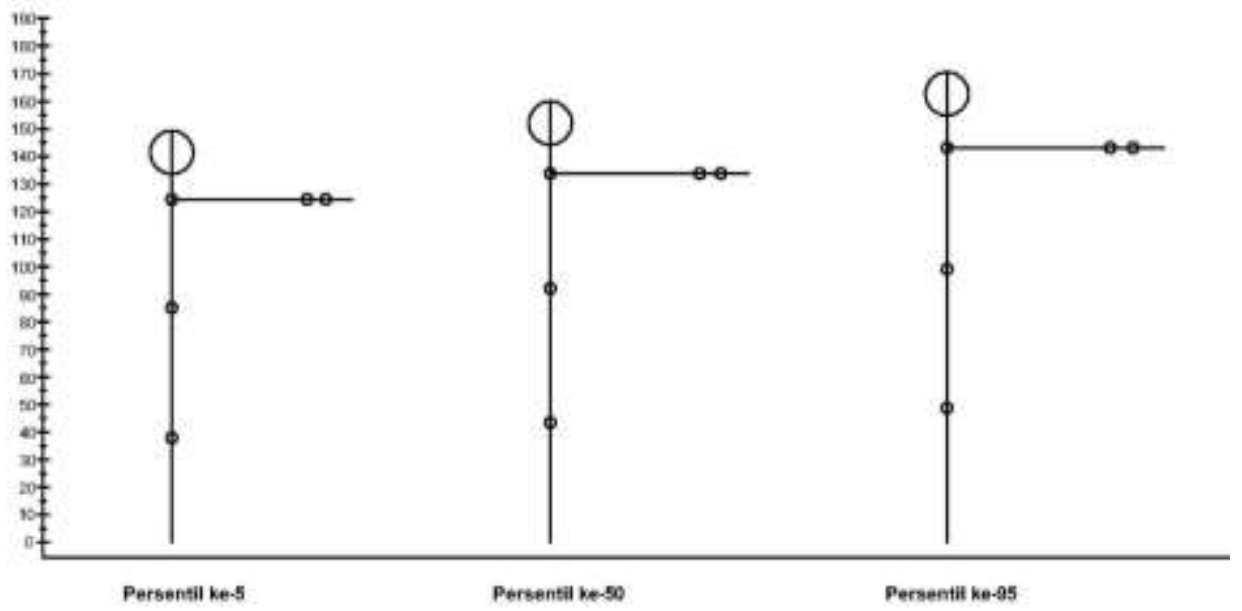

Gambar 1. Ilustrasi petani saat berdiri normal

Analisis ergonomi gerak kerja dilakukan untuk mengetahui tingkat kesesuaian prosedural kerja terhadap karakteristik alami fisiologi gerak pekerja sehingga selanjutnya dapat dianalisis resiko ergonomi yang mungkin terjadi pada pekerja panen (Syuaib, dkk., 2015).

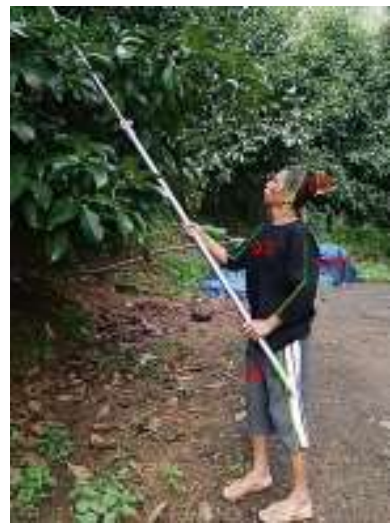

(a)

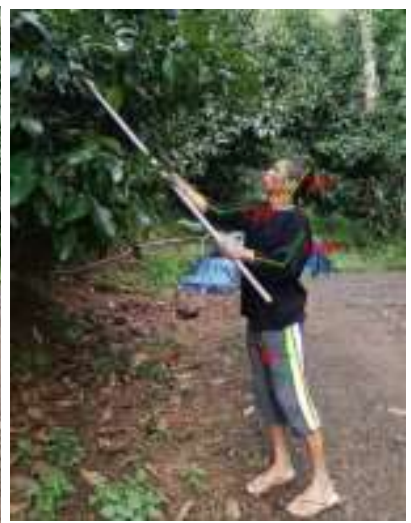

(b)

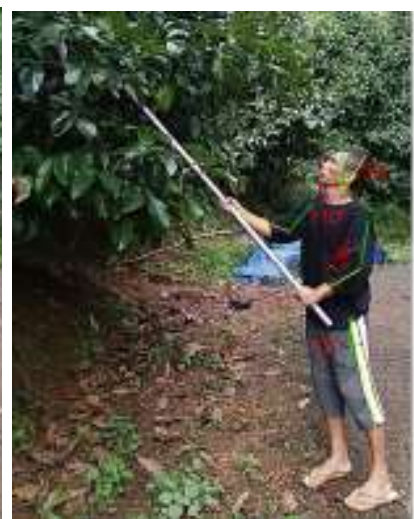

(c)

Gambar 2. Tahapan gerakan pemanenan manggis

Pemanenan manggis dilakukan dengan menggunakan sebuah batang bambu panjang dan kurang diperhatikan kenyamanan berdasarkan easpek ergonomi. Gerakan-gerakan pemanen dalam melakukan panen manggis dengan menggunakan alat panen memiliki karakteristik gerakan yang hampir sama untuk setiap responden, sehingga gambar yang di 
analisis untuk mengetahui selang alami gerak pemanen hanya 1 responden. Analisis selang gerak yang dianalisis digunakan referensi dalam melihat gerakan pemanen saat melakukan pemanenan. Pada penelitian ini diambil tahapan-tahapan yang penting dalam proses pemanenan yaitu mengarahkan alat hingga mengenai buah dan tangkai buah manggis berada diantara pengait, kemudian dengan gerakan sedikit mendorong alat panen hingga dipastikan buah tidak akan jatuh, dan terakhir adalah gerakan memutarkan alat panen hingga buah terlepas dari tangkai yang menyambung dengan buah yang disajikan pada Gambar 2 .

Gerakan-gerakan tersebut perlu diketahui derajat kesesuaian saat melakukan pemanenan terhadap selang alami gerakan (SAG) yang menganjurkan gerakan pada zona 0 dan zona 1 serta meminimalkan gerakan pada zona 2 dan 3, seperti yang disajikan pada Tabel 2 .

Tabel 2.

Zona selang alami gerak tubuh

\begin{tabular}{lccccc}
\hline & \multirow{2}{*}{ Gerakan } & \multicolumn{4}{c}{ Zona dan selang sudut gerak $\left(^{\circ}\right)$} \\
\cline { 3 - 6 } & & Zona 0 & Zona 1 & Zona 2 & Zona 3 \\
\hline Siku terhadap lengan tangan & Fleksi & $0-27$ & $28-62$ & $63-124$ & $124+$ \\
Pergelangan kaki & Ekstensi & $0-7$ & $8-18$ & $19-35$ & $36+$ \\
\multirow{2}{*}{ Lutut } & Fleksi & $0-5$ & $6-14$ & $15-28$ & $29+$ \\
& Fleksi & $0-21$ & $22-47$ & $47-94$ & $95+$ \\
Pinggul & Adduksi & $0-5$ & $6-12$ & $13-23$ & $24+$ \\
& Abduksi & $0-12$ & $13-27$ & $28-53$ & $54+$ \\
& Fleksi & $0-22$ & $23-50$ & $50-99$ & $100+$ \\
\hline
\end{tabular}

Sumber: Sanders dan McCormick dalam Rizki, 2013.

Dari hasil analisis gerak pemanen manggis (Gambar 2), gerakan leher mengalami ekstensi yang masih berada dalam zona 2 yaitu berada pada zona aman akan tetapi harus dihindari, gerakan lengan terhadap punggung mengalami ekstensi dan fleksi yang masih berada dalam zona 0 dan 1 yaitu berada pada zona aman. Petani manggis yang melakukan pemanenan tergolong berada di zona aman untuk setiap gerakan.

Derajat kesesuaian gerak pemanen dapat berbeda-beda untuk setiap pohon, diasumsikan lokasi pemanen saat melakukan pemanenan di lahan datar dengan jarak antara pemanen dengan pohon adalah 1,5 meter dan tinggi pohon 3 meter. Pohon manggis memiliki daun yang rimbun, sehingga buah manggis dapat tumbuh di ranting pohon, hal tersebut mengakibatkan jarak antara pemanen dengan pohon tidak dan tinggi pohon terlalu mempengaruhi derajat kesesuaian selang alami gerak, karena buah manggis dapat tumbuh pada ketinggian ranting 1 meter diatas permukaan tanah. Derajat kesesuaian selang alami gerak diketahui untuk batas aman saat melakukan pemanenan.

Berdasarkan data antropometri berdasarkan persentil 5, didapatkan dari tinggi petani $149 \mathrm{~cm}$, tinggi sandaran tangan $86,5 \mathrm{~cm}$, jangkauan tangan menggenggam keatas menggenggam $177,5 \mathrm{~cm}$ dan diameter tangan ibu jari dengan jari telunjuk $3,7 \mathrm{~cm}$. Parameter antropometri diameter genggaman ibu jari dengan jari telunjuk digunakan untuk mengetahui diameter genggaman yang sesuai dengan antropometri sehingga petani dapat merasa nyaman saat melakukan pemanenan. Dimensi alat yang memenuhi kriteria parameter antropometri memiliki panjang batang 3 meter dengan 2 sambungan teleskopik dan masing-masing panjang 1,5 meter yang mana hal tersebut harus dilakukan agar petani tidak kesulitan membawa alat panen serta tidak memperlambat proses pemanjangan alat panen pada saat pemanenan berlangsung jika memanfaatkan 3 sambungan teleskopik. Menurut Dul dan Weerdmeester (2008), jika tangan digunakan untuk melakukan sebuah pekerjaan, pegangan 
tangan harus memiliki diameter $3 \mathrm{~cm}$, sehingga jika diameter alat panen melebihi $3 \mathrm{~cm}$ akan membuat petani tidak nyaman menggunakan alat panen. Tidak adanya ukuran diameter batang yang sesuai, sehingga diameter yang diambil adalah diameter terdekat yaitu $3,1 \mathrm{~cm}$. Penggunaan pedangan dengan diameter batang $3,1 \mathrm{~cm}$ juga tidak berbeda jauh dengan diameter alat panen petani yang telah digunakan petani sebelumnya yaitu berukuran $2,5 \mathrm{~cm}$.

Dari panjang alat pemanenan tersebut dapat menjangkau tinggi pohon rerata 1 hingga 3 meter dan dapat menjangkau buah yang lebih tinggi sehingga petani tidak perlu naik ke pohon agar dapat menjangkau buah yang tingginya melebihi 3 meter, karena tinggi jangkauan tangan ke atas petani $177,4 \mathrm{~cm}$, hal tersebut dapat menambah pembawaan alat panen lebih dari 3 meter. Perbedaan diameter alat panen yang telah di desain berbeda dengan hasil antropometri petani pada persentil 5

Desain tangkai pengait yang baru dibuat sama dengan dengan tangkai pengait yang telah dimiliki petani, hal tersebut ditujukan untuk mendapatkan kualitas buah manggis yang baik. Alat panen yang dibuat memiliki kekurangan yaitu beban alat panen lebih berat dibandingkan alat panen petani yang terbuat dari bambu, seperti yang disajikan pada Gambar 3 .
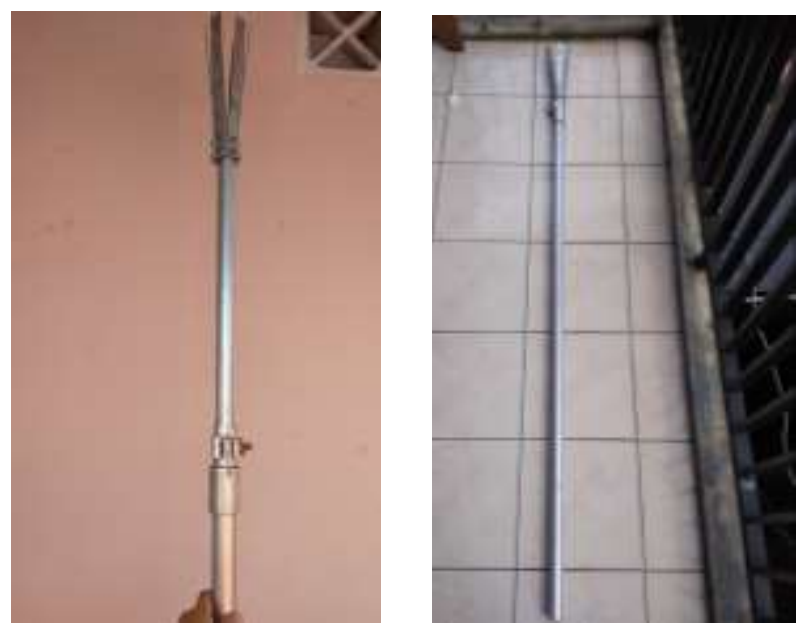

Gambar 3. Desain alat panen baru

\section{SIMPULAN}

Berdasarkan kajian terhadap proses pemanenan dan alat pemanen yang digunakan dapat direkomendasi panjang alat panen manggis adalah sambung 2 teleskopik dengan panjang batang masing-masing 1,5 meter dengan menggunakan material aluminium. Bagian tubuh yang berhubungan langsung dengan gerak kerja pada saat pemanenan adalah leher, bahu, dan lengan.

\section{UCAPAN TERIMA KASIH}

Ucapan terima kasih disampaikan kepada Bapak Sumpena selaku ketua kelompok tani manggis Artamukti di Kecamatan Puspahiang Kabupaten Tasikmalaya, Jawa Barat yang telah membantu kelancaran kegiatan penelitian.

\section{DAFTAR PUSTAKA}

Badan Pusat Statistik. 2017. Produksi Tanaman Manggis, BPS-Statistik Indonesia. https://www.bps.go.id/site/resultTab. 5 Maret 2019 (13:12) 
Dul, Jan dan Weerdmeester. B. 2008. Ergonomics for Begineers: a Quick Reference Guide. (3rd ed). New South Wales: CRC Press.

Gunadnya, I.B.P., Utama, Supartha I.M., dan Mahendra, M. S. 2001. Effects of Impact and Harvesting Indexes on the Quality of Mangosteen Frui. Buletin Keteknikan Pertanian. Vol. 15 No. 1. Denpasar: Universitas Udayana.

Arisandy, I. R. 2013. Studi Antropometri Dan Gerak Kerja Pemanen Kelapa Sawit Serta Aplikasinya Untuk Penyempurnaan Desain Alat Panen Sawit (Egrek Dan Dodos). (Skripsi). Bogor: Institut Pertanian Bogor.

Mugisa, D.J, A. Katimbo, E.J. Sempiira, dan W.S. Kisaalita. 2016. Anthropometric Characteristics of Female Smallholder Farmers of Uganda - Toward Design of LaborSaving Tools. Jurnal Applied Ergonomics. Vol. 54:177-185.

Muslim, C. dan Tjetjep, N. 2009. Competitiveness of Mangosteen: Export Promotion, Marketing System, and Stability in Domestic Market (A Case Study in Purwakarta Regency, West Java province). Vol. 29(1):87-111.

Nuraniputri. U., K. Henny, dan Kuntjoro. 2016. Produksi Manggis Pada Beberapa Kelompok Umur Tanaman dan Faktor-Faktor yang Mempengaruhi Produksi Manggis Di Kabupaten Sukabumi, Jawa Barat. Jurnal Agrivor. Vol. 4(1):67-78.

Vyavahare, R.T. dan S.P. Kallurkar. 2012. Anthropometric and Strength Data of Indian Agricultural Workers for equipment Design: Review. Jurnal Agric Eng Int: CIGR Journal. Vol. 14(4)(74):102-114.

Sutalaksana, I. Z dan A. Widyanti. 2016. Anthropometry Approach in Workplace Redesign in Indonesian Sundanese Roof Tile Industries. International Journal of Industrial Ergonomics. Vol. 53:299-305.

Syuaib, M. F., Dewi, N. S. dan Sari, T. N. 2015. Studi Gerak Kerja Pemanenan Kelapa Sawit Secara Manual. Jurnal Keteknikan Pertanian, Vol. 3(1):49-56.

Syuaib, M. F. 2015. Ergonomic of The Manual Harvesting Tasks of Oil-Palm Plantation in Indonesia Based on Anthropometric, Postures and Work Motions Analyses. Jurnal International Agricultural Engineering. Vol. 17(3):248-262. 